\title{
Operating authorization and certification of the vehicles under the regulations of the Fourth Railway Package
}

\section{Dopuszczenie do eksploatacji oraz certyfikacja pojazdów w świetle IV Pakietu Kolejowego}

\begin{abstract}
The paper includes information on the documents related to the $4^{\text {th }}$ Railway Package, the changes in directives and regulations and the threats caused by implementation of the package. The present paper makes a part of the study devoted to the changes to be introduced by the package.

The first part of the paper provides description of the Fourth Railway Package, inclusive of a brief characteristics of the assumptions of the three previous packages. The next part describes the documents related to the package along with the changes resulting from implementation of the Fourth Railway Package. In the last part of the paper, attention was paid to the risks and rules of putting the vehicles into service, commonly known as homologation and certification.
\end{abstract}

$W$ artykule zawarto informacje dotyczqce dokumentów zwiqzanych z IV Pakietem Kolejowym, zmian $w$ dyrektywach $i$ rozporzqdzeniach oraz zagrożen zwiqzanych $z$ wdrożeniem pakietu. Niniejszy artykut jest częściq opracowania zawierajacego opis zmian, które wprowadzi pakiet.

W pierwszej części artykułu został opisany czwarty pakiet kolejowy wraz z krótkq charakterystykq zatożeń trzech poprzednich pakietów. W kolejnej części zostaty opisane dokumenty powiazane z pakietem wraz ze zmianami wynikajacymi z wdrożenia czwartego pakietu kolejowego. W ostatniej części artykułu zwrócono uwagę na zagrożenia, a także przedstawiono zasady dopuszczania do eksploatacji, zwyczajowo zwanego homologacja oraz certyfikacji.

\section{Introduction}

The paper presents the assumptions of the $4^{\text {th }}$ Railway Package, legal regulations currently in force and detailed discussion of the package project (purpose, description and division). The analysis of changes and threats related to implementation of the $4^{\text {th }}$ Railway Package was carried out based on the following normative documents related to the package:

- Directive 2016/798 (Safety of the railway system);

- Directive 2016/797 (Interoperability of the railway system);

- Regulation 2016/796 (EU Railway Agency);

- Repeal of the regulation 1192/69 (Normalization of accounting);

- Amendment of the Regulation 1370/2007 (Opening of the passenger market); and

- Amendment of the Directive 2012/34 (Single European Railway Area).

\section{Wprowadzenie}

W artykule przedstawiono założenia IV Pakietu Kolejowego, regulacje prawne obowiązujące obecnie oraz omówiono szczegółowo projekt pakietu (cel, opis i podział). Przeprowadzono analize zmian oraz zagrożeń związanych z wdrożeniem IV Pakietu Kolejowego na podstawie niżej wymienionych dokumentów normatywnych, związanych z pakietem:

- Dyrektywa 2016/798 (Bezpieczeństwo systemu kolejowego)

- Dyrektywa 2016/797 (Interoperacyjność systemu kolei)

- Rozporządzenie 2016/796 (Agencja Kolejowa UE)

- Uchylenie Rozporządzenia 1192/69 (Normalizacja rachunkowości)

- Zmiana Rozporządzenia 1370/2007 (Otwarcie rynku pasażerskiego) oraz

- Zmiana Dyrektywy 2012/34 (Jednolity Europejski Obszar Kolejowy). 
The principles of operating authorization and certification have been characterized and presented, in accordance with the Directive 2008/57/EC of 17 June 2008 issued by the European Parliament and the Council, on the interoperability of the rail system in the community.

\section{The first Railway Packages}

Despite extensive and detailed regulations imposing the rules of the common rail market, it turns out that the process of their implementation takes place with many difficulties and is much slower than expected. The effects obtained, namely the change in the structure of the market and the volume of rail transport, also depart from the expected ones. Nevertheless, the European Commission remains fully committed to the chosen path of railway transformation and, at the same time, development of a common, single rail market is one of the main objectives of European transport policy for the present decade. In order to clarify the rules for operation of the European transport policy, the First Railway Package was established and adopted in 2001. Under the First Railway Package, the following legal regulations have been issued:

- Directive 2001/12/WE

- Directive 2001/13/WE

- Directive 2001/14/WE

- Directive 2001/16/WE

The main recommendations of the above legal acts were:

- availability of the segregated TERFN (Trans European Rail Freight Network) network for international freight transport;

- organizational separation of infrastructure management entities and the ones engaged in transportation;

- a license valid in the whole EU instead of a concession;

- the rolling stock and its crew are required to hold safety certificates;

- principles for allocation of infrastructure routes;

- principles of charging for access to the network;

- appointment of an independent railway regulatory institution;

- establishing the rules for implementation of interoperability of the conventional rail system, with regard to the design, construction, handling and operation [3].

In April 2004 the Second Railway Package [4] has been adopted, the legal acts of which were aimed, among others, at:

- full opening of the rail market for the freight transport;
Scharakteryzowano i przedstawiono zasady dopuszczania do eksploatacji oraz certyfikacji według Dyrektywy Parlamentu Europejskiego i Rady 2008/57/WE z dnia 17 czerwca 2008 r. w sprawie interoperacyjności systemu kolei we wspólnocie.

\section{Pierwsze pakiety kolejowe}

Mimo obszernych i szczegółowych regulacji, narzucających zasady funkcjonowania wspólnego rynku kolejowego, okazuje się, że proces ich implementacji przebiega znacznie wolniej i z większymi oporami niż zakładano. Uzyskane efekty, w postaci zmienionej struktury podmiotowej rynku i wielkości przewozów kolejami również odbiegają od oczekiwanych. Komisja Europejska, mimo to w pełni podtrzymuje wybraną drogę przekształceń kolei, a dokończenie procesu budowy wspólnego, jednolitego rynku kolejowego stanowi jeden z głównych celów europejskiej polityki transportowej na obecną dekadę. W celu doprecyzowania reguł funkcjonowania europejskiej polityki transportowej ustanowiono Pierwszy pakiet kolejowy, który został przyjęty w roku 2001. W ramach pierwszego pakietu kolejowego wprowadzono następujące regulacje prawne:

- Dyrektywa 2001/12/WE

- Dyrektywa 2001/13/WE

- Dyrektywa 2001/14/WE

- Dyrektywa 2001/16/WE

Głównymi zaleceniami ww. aktów prawnych były:

- dostęp do wydzielonej sieci TERFN (Trans European Rail Freight Network) dla międzynarodowych przewozów towarowych

- rozdzielenie organizacyjne jednostek zarządzających infrastrukturą i wykonujących przewozy

- licencja zamiast koncesji z ważnością na całą UE

- wymóg posiadania certyfikatu bezpieczeństwa dla taboru i dla załogi

- zasady przydziału tras infrastruktury

- zasady naliczania opłat za dostęp do sieci

- powołanie niezależnej instytucji regulatora kolei

- ustanowienie zasad wdrożenia interoperacyjności systemu kolei konwencjonalnych, w odniesieniu do projektowania, konstrukcji, obsługi i eksploatacji

W kwietniu 2004 r. przyjęto Drugi pakiet kolejowy, którego akty prawne miały na celu $\mathrm{m}$. in.:

- pełne otwarcie rynku kolejowego dla przewozów towarowych

- usunięcie przeszkód występujących w transgranicznych usługach kolejowych

- utworzenie Europejskiej Agencji Kolejowej $(E R A)$, jako technicznego wsparcia dla interoperacyjności i bezpieczeństwa kolei 
- removing obstacles in cross-border rail services;

- establishment of the European Railway Agency $(E R A)$ providing technical support for railway interoperability and safety;

- establishment of common safety rules for the rail transport with a view to increase the safety level.

Under the aforementioned package the following legal regulations have been implemented:

- Directive 2004/49/WE

- Directive 2004/50/WE

- Directive 2004/51/WE

- Regulation (WE) No 881/2004

In December 2007 the Third Railway Package appeared, consisting of three normative documents:

- Directive 2007/58/WE

- Directive 2007/59/WE

- Regulation 1370/2007/WE

The main objective of the package was aimed at improving the quality of services provided in the field of rail transport.

\section{The Fourth Railway Package}

\subsection{Introductory remarks}

The fourth railway package is a set of six legislative documents designed with a view to complement the single market of the rail services (a single European railway area) composed of two pillars: the technical and economic ones. The package includes the following normative documents:

- Regulation nr 2016/796

- Directive 2016/797

- Directive 2016/798

- Regulation nr 2016/2338

- Directive 2016/2370 oraz

- Regulation nr 2016/2337, described in detail under paragraph 4 .

The proposals of the Fourth Railway Package have specific objectives. Implementation of the package is aimed, among others, at reducing the costs incurred by the railway companies existing on the market, and facilitating market entry for new players. In addition, the role of infrastructure managers should be strengthened in result of independence (financial and/or operational) from the train operators. The managers will also be able to control the areas of the network center - the timetable or maintenance. In addition, from December 2019, the domestic railways will be open for new entities and services. This shall improve the opportunity to offer a railway service on a given route or to apply for public procurement by tender.

The changes are aimed at removing the remaining barriers impeding creation of a uniform European rail market, promoting competitiveness and innovation in domestic passenger markets. The final result of the
- ustanowienie wspólnych zasad bezpieczeństwa w transporcie kolejowym w celu podniesienia poziomu tego bezpieczeństwa.

W ramach ww. pakietu wprowadzono następujące regulacje prawne:

- Dyrektywa 2004/49/WE

- Dyrektywa 2004/50/WE

- Dyrektywa 2004/51/WE oraz

- Rozporządzenie (WE) nr 881/2004.

W grudniu 2007 r. pojawił się Trzeci pakiet kolejowy, który składał się $\mathrm{z}$ trzech dokumentów normatywnych:

- Dyrektywy 2007/58/WE

- Dyrektywy 2007/59/WE oraz

- Rozporządzenia 1370/2007/WE.

Głównym celem ustanowienia pakietu było podniesienie jakości świadczonych usług w kontekście transportu kolejowego.

\section{Czwarty Pakiet Kolejowy}

\subsection{Uwagi wstępne}

Czwarty pakiet kolejowy to zestaw sześciu dokumentów legislacyjnych opracowanych w celu uzupełnienia jednolitego rynku usług kolejowych (jednolitego europejskiego obszaru kolejowego) składającego się z dwóch filarów: technicznego oraz ekonomicznego. W skład pakietu wchodzą dokumenty normatywne:

- Rozporządzenie nr 2016/796

- Dyrektywa 2016/797

- Dyrektywa 2016/798

- Rozporządzenie nr 2016/2338

- Dyrektywa 2016/2370 oraz

- Rozporządzenie nr 2016/2337,

które zostały szczegółowo opisane w punkcie 4.

Propozycje zawarte w Czwartym pakiecie kolejowym mają konkretne cele. Między innymi celem wdrożenia pakietu jest zmniejszenie kosztów ponoszonych przez istniejące na rynku przedsiębiorstwa kolejowe, a nowym podmiotom ułatwienie wejścia na rynek. Ponadto rola zarządców infrastruktury powinna się umocnić w ramach niezależności (finansowej i/lub operacyjnej) od operatorów pociągów. Zarządcy będą mogli również kontrolować obszary centrum sieci - rozkład jazdy czy konserwację. Dodatkowo, od grudnia 2019 roku, będzie możliwe otwarcie krajowych kolei dla nowych podmiotów i usług, co wiąże się z większą możliwością zaoferowania np. usługi kolejowej na określonej trasie lub ubiegania się o zamówienia publiczne drogą przetargu.

Zmiany mają na celu usunięcie pozostałych barier w tworzeniu jednolitego europejskiego rynku kolejowego, wspieranie konkurencyjności i innowacji na krajowych rynkach pasażerskich. Końcowym rezultatem wdrożenia pakietu powinien być przede wszystkim wyższy poziom bezpieczeństwa, interoperacyjności, ale także niezawodności w europejskiej sieci kolejowej. 
package implementation should be, first of all, a higher level of security, interoperability, and also reliability in the European rail network.

\subsection{Technological Pillar}

The technical pillar includes interoperability, safety authorization, the certification of track-side ERTMS equipment, but also the limitation of national regulations and increased role of the Agency (ERA) with respect to licensing and certification policy. The following documents are related to the technical pillar:

- Regulation No 2016/796 of the European Parliament and of the EU Council of May 11, 2016 on the European Railway Agency and the repeal of Regulation (EC) No 881/2004;

- Directive of the European Parliament and of the EU Council No 2016/797 of May 11, 2016.

on the interoperability of the rail system in the European Union;

- Directive of the European Parliament and of the EU Council No 2016/798 of May 11, 2016.

on railway safety.

\subsection{Economic Pillar}

The economic pillar (also called the market one) is linked to the opening of the market to passenger transport services, infrastructure management and accounting normalization. The following documents relate to the economic pillar:

- Regulation No 2016/2338 of the European Parliament and of the EU Council of December 14, 2016 amending the EC Regulation No 1370/2007 related to the opening of the market in domestic passenger transport services by rail;

- Directive of the European Parliament and of the EU Council No 2016/2370 of December 14, 2016 amending the Directive 2012/34/EU related to the opening of the market for domestic rail passenger services and the management of railway infrastructure;

- Regulation No 2016/2337 of the European Parliament and of the EU Council of December 14, 2016 repealing the EEC Council Regulation No. 1192/69 on common rules normalizing the accounting of the railway companies.

4. Normative documents related to the $4^{\text {th }}$ Railway Package

4.1. Regulation of the European Parliament and of the EU Council No 2016/796

The Regulation No 2016/796 of the European Parliament and of the EU Council of May 11, 2016 on the European Railway Agency and the repeal of Regulation (EC) No 881/2004 establishes the

\subsection{Filar techniczny}

Filar techniczny dotyczy interoperacyjności, autoryzacji w zakresie bezpieczeństwa, certyfikacji przytorowych urządzeń ERTMS, ale także ograniczenia krajowych przepisów i zwiększonej roli Agencji (ERA) w zakresie wydawania zezwoleń i certyfikacji. Do filaru technicznego odnoszą się następujące dokumenty:

- Rozporządzenie Parlamentu Europejskiego i Rady (UE) nr 2016/796 z dnia 11 maja 2016 r. w sprawie Agencji Kolejowej Unii Europejskiej i uchylenia rozporządzenia (WE) nr 881/2004;

- Dyrektywa Parlamentu Europejskiego i Rady (UE) 2016/797 z dnia 11 maja 2016 r. w sprawie interoperacyjności systemu kolei w Unii Europejskiej;

- Dyrektywa Parlamentu Europejskiego i Rady (UE) 2016/798 z dnia 11 maja 2016 r. w sprawie bezpieczeństwa kolei.

\subsection{Filar ekonomiczny}

Filar ekonomiczny (zwany także rynkowym) dotyczy otwarcia rynku na usługi transportu pasażerskiego, zarządzania infrastrukturą, a także normalizacji rachunkowości. Do filaru ekonomicznego odnoszą się następujące dokumenty:

- Rozporządzenie Parlamentu Europejskiego i Rady (UE) nr 2016/2338 z dnia 14 grudnia 2016 r. zmieniające rozporządzenie (WE) nr 1370/2007 w odniesieniu do otwarcia rynku krajowych usług kolejowego transportu pasażerskiego;

- Dyrektywa Parlamentu Europejskiego i Rady (UE) 2016/2370 z dnia 14 grudnia $2016 \mathrm{r}$. zmieniająca dyrektywę 2012/34/UE w odniesieniu do otwarcia rynku krajowych kolejowych przewozów pasażerskich oraz zarządzania infrastrukturą kolejową;

- Rozporządzenie Parlamentu Europejskiego i Rady (UE) nr 2016/2337 z dnia 14 grudnia 2016 r. uchylające rozporządzenie Rady (EWG) nr 1192/69 w sprawie wspólnych zasad normalizujących rachunkowość przedsiębiorstw kolejowych.

\section{Dokumenty normatywne związane z IV Pakie- tem Kolejowym}

\subsection{Rozporządzenie Parlamentu Europejskiego i}

Rady (UE) nr 2016/796

Rozporządzenie Parlamentu Europejskiego i Rady (UE) nr 2016/796 z dnia 11 maja 2016 r. w sprawie Agencji Kolejowej Unii Europejskiej i uchylenia rozporządzenia (WE) nr 881/20014 ustanawia Agencję Kolejową Unii Europejskiej (zwaną również Agencją) wraz z określeniem zakresu działań Agencji, a także określenie zadań dla państw członkowskich Unii Europejskiej. Rozporządzenie to ma na celu wspieranie tworzenia jednolitego europejskiego obszaru kolejowego, a w szczególności interoperacyjności w ramach 
European Railway Agency (also known as the Agency), defines the scope of the Agency activities, as well as the tasks of the European Union Member States. This regulation is aimed at supporting the creation of a single European railway area, and in particular, ensuring the interoperability within the European Union rail system, the safety of the European Union rail system and the certification of train drivers - Directive 2007/59/EC.

\subsection{Directive of the European Parliament and of the EU Council No 2016/797}

The Directive of the European Parliament and of the EU Council No 2016/797 of May 11, 2016. on the interoperability of the rail system in the European Union defines the conditions whose fulfillment leads to achieving interoperability within the European Union rail system. Such conditions include, among others, the design, construction, renewal or modernization of the infrastructure, professional qualifications or health requirements of the staff. The objective of the above conditions consists, first of all, in the development and improvement of rail transport services, as well as the definition of the optimal level of technological harmonization and promotion of the rail market unification. The Directive lays down the rules on interoperability constituents, interfaces, procedures and conditions necessary to ensure the compliance of the entire European Union rail system required to achieve the interoperability.

\subsection{Directive of the European Parliament and of the EU Council No 2016/798}

The Directive of the European Parliament and of the EU Council No 2016/798 of May 11, 2016.on railway safety specifies the provisions required with a view to ensure the development and improvement of the system security and to improve access to the rail market for the transport services. The above mentioned goals can be achieved, among others, through:

- harmonizing the regulatory structure in the Member States:

- determination of responsibility of the operators;

- development of common safety requirements and methods for safety assessment, and

- defining common principles of safety management and revocation or limitation of the security certificates.

The directive covers safety requirements for the entire system (structural and functional subsystems) without the exclusion of infrastructure management, train traffic, cooperation between the companies and other operators of the European Union rail system.

\subsection{Regulation of the European Parliament and of the EU Council No 2016/2338 \\ The Regulation of the European Parliament and of the EU Council No 2016/2338 of December 14, 2016}

systemu kolei Unii Europejskiej, bezpieczeństwa systemu kolei Unii Europejskiej oraz przyznawania uprawnień maszynistom - Dyrektywa 2007/59/WE.

\subsection{Dyrektywa Parlamentu Europejskiego i Rady (UE) 2016/797}

Dyrektywa Parlamentu Europejskiego i Rady (UE) 2016/797 z dnia 11 maja 2016 r. w sprawie interoperacyjności systemu kolei w Unii Europejskiej określa warunki, których spełnienie prowadzi do osiąnnięcia interoperacyjności w obrębie systemu kolei w Unii Europejskiej. Do takich warunków zalicza się m.in.: projektowanie, budowę, odnowienie lub modernizację, kwalifikacje zawodowe lub wymagania zdrowotne personelu. Celem spełnienia ww. warunków jest przede wszystkim rozwój i doskonalenie usług transportu kolejowego, a także zdefiniowanie optymalnego poziomu harmonizacji technicznej oraz przyczynienie się do ujednolicenia rynku kolejowego. Dyrektywa ustanawia przepisy dotyczące składników interoperacyjności, interfejsów i procedur oraz warunków potrzebnych do spełnienia zgodności całego systemu kolei Unii Europejskiej, koniecznych do osiagniecia interoperacyjności.

\subsection{Dyrektywa Parlamentu Europejskiego i Rady (UE) 2016/798}

Dyrektywa Parlamentu Europejskiego i Rady (UE) 2016/798 z dnia 11 maja 2016 r. w sprawie bezpieczeństwa kolei określa przepisy potrzebne do zapewnienia rozwoju i doskonalenia bezpieczeństwa systemu oraz poprawienia dostępu do rynku kolejowego dla usług transportowych. Ww. cele można osiagnąć m.in. poprzez:

- harmonizację struktury regulacyjnej w państwach członkowskich

- określenie odpowiedzialności dla podmiotów

- rozwój wspólnych wymagań bezpieczeństwa i metod oceny bezpieczeństwa oraz

- określenie wspólnych zasad zarządzania bezpieczeństwem i cofnięcia lub ograniczenia stosowania certyfikatów bezpieczeństwa.

Dyrektywa obejmuje wymogi bezpieczeństwa dla całego systemu (podsystem strukturalny i podsystem funkcjonalny) bez wyłączenia zarządzania infrastrukturą i ruchem pociągów, współdziałania przedsiębiorstw i innych podmiotów systemu kolei Unii Europejskiej.

\subsection{Rozporządzenie Parlamentu Europejskiego i Rady (UE) nr 2016/2338}

Rozporządzenie Parlamentu Europejskiego i Rady (UE) 2016/2338 z dnia 14 grudnia 2016 r. zmieniające rozporządzenie (WE) nr 1370/2007 w odniesieniu do otwarcia rynku krajowych usług kolejowego transportu pasażerskiego ma jako główny cel podniesienie poziomu jakości, przejrzystości, a także sprawności i efektywności usług publicznych w zakresie kolejowego transportu pasażerskiego. Największą zmianą w 
amending the EC Regulation No 1370/2007 related to the opening of the market in domestic passenger transport services by rail is mainly aimed at the improvement of the quality, transparency, efficiency and effectiveness of public services in the field of rail passenger transport. The major change with respect to the EC Regulation No 1370/2007 is the addition of two Articles "Rolling Stock" and "Specifications for public service obligations".

\subsection{Directive of the European Parliament and of the EU Council No 2016/2370}

The Directive of the European Parliament and of the EU Council No 2016/2370 of December 14, 2016 amending the Directive 2012/34/EU related to the opening of the market for domestic rail passenger services and the management of railway infrastructure establishes common rules for the management of railway companies and financing, infrastructure managers, charging for access to the infrastructure concerned, conditions of the access and supervision of the railway market. The Directive includes the provisions setting independence of the infrastructure manager, independence of the basic functions, impartiality of the infrastructure manager, commissioning and sharing the functions of the infrastructure manager, financial transparency, coordination mechanisms, the networks of the infrastructure managers, passenger transport by highspeed railways and integrated information systems and common ticket systems.

\subsection{Regulation of the European Parliament and of the EU Council No 2016/2337 \\ The Regulation of the European Parliament and of the EU Council No 2016/2337 of December 14, 2016 on common rules normalizing the accounting of the railway companies revokes the EEC Council Regulation No. 1192/69.}

\section{Amendments to the Act on railway transport}

The Act on railway transport of March 28, 2003 (Journal of Laws 2003, No 86, Item 789) provides, among others:

- the rules for the use, maintenance and management of the railway infrastructure;

- the rules of railway traffic and transport;

- technical conditions of the railway vehicles operation, and

- the conditions ensuring the interoperability of the railway system on the Polish territory.

In December 2016, a law changing the law on railway transport came into force, i.e. the Act of November 16,2016 , amending the act on railway transport and some other acts (item 1923), being the result of the $4^{\text {th }}$ Railway Package implementation.

General changes related to the railway operators include the regulations changing the rules of railway transport licensing, which entered into force on May odniesieniu do rozporządzenia (WE) nr 1370/2007 jest dodanie dwóch artykułów: „Tabor kolejowy” oraz „Specyfikacje zobowiazań z tytułu świadczenia ustug publicznych.".

\subsection{Dyrektywa Parlamentu Europejskiego i Rady (UE) 2016/2370}

Dyrektywa Parlamentu Europejskiego i Rady (UE) 2016/2370 z dnia 14 grudnia 2016 r. zmieniająca dyrektywę 2012/34/UE w odniesieniu o otwarcia rynku krajowych kolejowych przewozów pasażerskich oraz zarządzania infrastrukturą kolejową ustanawia wspólne zasady dotyczące zarządzania przedsiębiorstwami kolejowymi i finansami, zarządcami infrastruktury, pobierania opłat za dostęp do danej infrastruktury, warunków dostępu do infrastruktury a także nadzoru nad rynkiem kolejowym. Dyrektywa posiada zapisy dotyczące: niezależności zarządcy infrastruktury; niezależności funkcji podstawowych; bezstronności zarządy infrastruktury; zlecenia i współdzielenia funkcji zarządy infrastruktury; przejrzystości finansowej; mechanizmów koordynacyjnych; sieci zarządców infrastruktury; przewozów pasażerów kolejami dużych prędkości oraz zintegrowanych systemów informacji i systemów wspólnego biletu.

\subsection{Rozporządzenie Parlamentu Europejskiego i Rady (UE) nr 2016/2337}

Rozporządzenie Parlamentu Europejskiego i Rady (UE) 2016/2337 z dnia 14 grudnia 2016 r. uchylające rozporządzenie Rady (EWG) nr 1192/69 w sprawie wspólnych zasad normalizujących rachunkowość przedsiębiorstw kolejowych, który wprowadzona decyzję o uchyleniu rozporządzenia Rady (EWG) nr $1192 / 69$.

\section{Zmiany w ustawie o transporcie kolejowym}

Ustawa z dnia 28 marca 2003 r. o transporcie kolejowym (Dz. U. 2003 Nr 86 poz. 789) określa m.in.:

- zasady korzystania, utrzymania i zarządzania infrastrukturą kolejową

- zasady prowadzenia ruchu i wykonywania przewozów kolejowych

- warunki techniczne eksploatacji pojazdów kolejowych oraz

- warunki zapewnienia interoperacyjności systemu kolei na terytorium Polski.

W grudniu 2016 r. w życie weszła ustawa, która zmienia ustawę o transporcie kolejowym - Ustawa z dnia 16 listopada 2016 r. o zmianie ustawy o transporcie kolejowym oraz niektórych innych ustaw (poz. 1923) - co jest skutkiem wdrażania IV Pakietu Kolejowego.

Do ogólnych zmian dotyczących przedsiębiorców kolejowych można zaliczyć przepisy, które zmieniaja zasady licencjonowania transportu kolejowego, a które weszły w życie 30 maja 2017 roku. Zmiany występują także w procedurze autoryzacji bezpieczeństwa, 
30, 2017. The changes arise also in the procedures of safety authorization, safety certification and issuing of safety certificates. Nevertheless, all the abovementioned documents issued before the date of entry into force of this Act remain valid until their expiration dates. Therefore, the railway operators and infrastructure managers have the right to carry on their business based on the above-mentioned documents, provided that they were issued prior to the date of entry into force of the aforesaid law. The same principle also applies to the decisions on granting open access to railway infrastructure, rules, pricelists and timetables.

Among more detailed changes in the Act there are the ones related to definition of the groups of railway carriers, infrastructure managers and railway siding users. A railway carrier (according to the definition) is an operator authorized, under a license, to perform railway transport or to provide traction service or an entity performing transport on the infrastructure of narrow-gauge railway [1].

Particular case of a railway carrier is the so-called "Applicant", i.e. a railway carrier, an international group of economic interests including the rail carriers or another entities interested in acquiring capacity, in particular an organizer of public rail transport, a forwarder, a sender or a combined transport operator [1].

An infrastructure manager is an entity responsible for managing the railway infrastructure or, in the case of building new infrastructure, an entity that has started to build it as an investor. The tasks of the infrastructure manager can be performed by various entities [1].

A railway siding user is an infrastructure manager who does not manage another railway route than a railway siding [1].

\section{The threats related to the implementation of the $4^{\text {th }}$ Railway Package}

Taking into account the documents listed in this article the threats related to implementation of the $4^{\text {th }}$ Railway Package based on the pillars referred to in the points 3.2 and 3.3 , i.e. the threats resulting from technical acts and the threats related to management projects and market opening, may be divided into two groups.

The main threats resulting from the implementation of the technical documentation of the $4^{\text {th }}$ Railway Package (first group) include:

- designation of the decisive role of the European Railway Agency (ERA) in the railway vehicle approvals and the possible extension of the time limits for obtaining authorization for operation;

- coordination of introduction of common regulations in particular countries by ERA. Consequently, the infrastructure and rolling certyfikacji bezpieczeństwa oraz wydawania świadectw bezpieczeństwa, natomiast wszelkie ww. dokumenty wydane przed dniem wejścia w życie niniejszej ustawy zachowują swoją ważność aż do daty utraty ważności. W związku w tym, przewoźnicy kolejowi oraz zarządcy infrastruktury mają prawo prowadzić swoją działalność na podstawie wydanych ww. dokumentów pod warunkiem, że zostały one wydane przed datą wejścia w życie omawianej ustawy. Taka sama zasada obowiązuje również w sprawie decyzji o przyznaniu otwartego dostępu do infrastruktury kolejowej oraz regulaminów, cenników i rozkładów jazdy.

Do bardziej szczegółowych zmian w ustawie można zaliczyć zmiany, które dotyczą definicji grup przewoźników kolejowych, zarządców infrastruktury oraz użytkowników bocznicy kolejowej. Przewoźnik kolejowy (według definicji) to przedsiębiorca uprawniony na podstawie licencji do wykonywania przewozów kolejowych lub świadczenia ustugi trakcyjnej lub podmiot wykonujacy przewozy na infrastrukturze kolei waskotorowej.

Do szczególnego przypadku przewoźnika kolejowego należy tzw. „aplikant”, czyli przewoźnik kolejowy, międzynarodowe ugrupowanie interesów gospodarczych obejmujace przewoźników kolejowych lub inny podmiot zainteresowany uzyskaniem zdolności przepustowej, w szczególności organizator publicznego transportu kolejowego, spedytor, nadawca tadunku lub operator transportu kombinowanego.

Zarządca infrastruktury to podmiot odpowiedzialny za zarzadzanie infrastruktura kolejowq albo, w przypad$k u$ budowy nowej infrastruktury, podmiot, który przystapit do jej budowy w charakterze inwestora; zadania zarzqdcy infrastruktury mogq wykonywać różne podmioty.

Użytkownik bocznicy kolejowej to zarzqdca infrastruktury, który nie zarzadza inna droga kolejowa niż bocznica kolejowa.

\section{Zagrożenia związane z wdrożeniem IV Pakie- tu Kolejowego}

Zagrożenia związane z wdrożeniem IV Pakietu Kolejowego, w odniesieniu do wymienionych $\mathrm{w}$ niniejszym artykule dokumentów, na podstawie filarów opisanych $\mathrm{w}$ punkcie 3.2 oraz 3.3 , czyli zagrożenia wynikające $\mathrm{z}$ aktów technicznych oraz zagrożenia związane z projektami zarządzania oraz otwarcia ryn$\mathrm{ku}$, można podzielić na dwie grupy.

Główne zagrożenia wynikające $\mathrm{z}$ wdrożenia dokumentacji technicznej czwartego pakietu kolejowego (pierwsza grupa) to m.in.:

- wprowadzenie centralnej roli Europejskiej Agencji Kolejowej (ERA) w przeprowadzaniu dopuszczeń do ruchu pojazdów kolejowych i związane z tym możliwe wydłużenie terminów uzyskania dopuszczenia do eksploatacji 
- stock must be adapted to the requirements of the European Union (EU) in a time shorter than the conditions of the given country allow (e.g. the budget, the number of the companies dealing with the modernization or length of the railway line) or shorter than the terms adopted by the inspections in the Member States, i.e. in Poland by the Office of Rail Transport (UTK) and the notified bodies. Therefore, it will be possible to undermine the accreditation held by an entity, to create a language barrier and the need to keep, for example, the system documentation in other than Polish language.

Another threat for the above mentioned sphere consists in:

- appointing the ERA members - the ERA composition is difficult to define, including e.g. a representative of trade unions;

- The ERA means of subsistence should originate from the income, i.e. among others from the fees obtained from issued certificates. This may result in growth of the prices of the vehicle approvals.

- Transfer of the "Member State competence" to ERA, which will result in disregard of specificity of each country. The approval document issued for a given EU area should take into account the entire railway network and the conditions of each country.

Moreover, adoption of the term "accredited own entity of the applicant" enables certification of own products (in several modules) of the manufacturer. This may be contrary to the requirements regarding impartiality and independence of the notified bodies.

Among the threats resulting from the technical documents the following, among others, may be mentioned:

- elimination of national regulations resulting from the specificity of the country;

- approval of the decisions on changes in regulations by ERA, resulting in disregard of the country's proposals and arguments, and imposing e.g. adaptation of the rolling stock to new requirements;

- issuing a uniform certificate by ERA, resulting in possible extended time period for issuance of certificates and increased fee for the certificate.

Taking into account the above threats resulting from implementation of the $4^{\text {th }}$ Railway Package it should be noticed that the ERA activities aimed at coordinating the entire European railway market may become inefficient. This may lead to difficulties in railway operation in the community.

The second group of the threats related to the opening of the European rail market includes, among others:
- koordynacja wprowadzania wspólnych przepisów $\mathrm{w}$ poszczególnych krajach przez ERA, a związane $\mathrm{z}$ tym nakładanie obowiązku dostosowania infrastruktury i taboru do wymagań Unii Europejskiej (UE) w czasie krótszym niż pozwalają na to warunki danego kraju (np. budżet, liczba przedsiębiorstw modernizujących lub długość linii kolejowej) lub kontrole w państwach członkowskich, czyli w Polsce kontrola Urzędu Transportu Kolejowego (UTK) oraz jednostek notyfikowanych. Możliwe zatem będzie podważenie akredytacji posiadanej przez jednostkę, tworzenie bariery językowej oraz konieczność prowadzenia dokumentacji np. systemowej w innym języku niż polski.

Kolejnym zagrożeniem dla ww. obszaru to:

- powoływanie składu ERA - trudno definiowalny skład ERA, np. z przedstawicielem związków zawodowych

- utrzymywanie ERA z dochodów m. in. $z$ opłat za wydane certyfikaty, czyli możliwa podwyżka cen homologacji pojazdów oraz

- zmiana pozbawiająca kompetencji ,państwa czlonkowskiego" na kompetencje ERA, co przełozy się na brak uwzględnienia specyfiki $\mathrm{w}$ danym kraju. Dokument dopuszczający na dany teren UE powinien uwzględniać całą sieć kolejową i uwarunkowania każdego kraju.

Dodatkowo, wprowadzenie podmiotu ,akredytowana jednostka wtasna wnioskodawcy” otwiera możliwość certyfikacji swoich wyrobów (w kilku modułach) przez producenta. Taka możliwość może być sprzeczna $\mathrm{z}$ wymaganiami dotyczącymi bezstronności i niezależności stawianymi jednostkom notyfikowanym.

Do zagrożeń wynikających z dokumentów technicznych można także zaliczyć m. in.:

- eliminację przepisów krajowych wynikających ze specyfiki kraju

- zatwierdzanie decyzji o zmianach przepisów przez ERAczyli możliwość nieuwzględnienia propozycji i argumentów kraju i nakazanie np. dostosowania taboru do nowych wymagań

- wydawanie certyfikatu (jednolitego) przez ERA, czyli możliwość wydłużenia czasu oczekiwania na wydanie certyfikatów oraz podwyższenia opłaty za certyfikat.

Biorąc pod uwagę ww. zagrożenia wynikające $\mathrm{z}$ wdrożenia czwartego pakietu kolejowego można stwierdzić, że działania ERA jako koordynatora całego europejskiego rynku kolei mogą stać się nieefektywne, co może spowodować utrudnienia w działaniu kolei we wspólnocie.

Do drugiej grupy zagrożeń związanych z otwarciem europejskiego rynku kolei są można zaliczyć $m$. in.:

- możliwość oferowania usług kolejowych przez zagraniczne przedsiębiorstwa na polski rynek, co może grozić likwidacją polskich, a w szcze- 
- the railway services offered to the Polish market by foreign companies, which may threaten to eliminate the Polish and, in particular, the local companies, e.g. the regional railways;

- lack of competitiveness of Polish carriers as compared to the others, as a result of inferior rolling stock and lower expenditures for modernization;

- possible use of dumped prices (i.e. sales of goods and services below the cost of their production or service or resale below the cost of purchase with a view to eliminate other entrepreneurs) by large foreign carriers in Poland. This might result in shutdown of the local companies on the market or elimination of the existing distinction between the international and domestic traffic, requiring quick modernization of particular lines or their liquidation.

Furthermore, the most costly threat in this group may be caused by the establishment of shared information systems and integrated ticket systems for all the railway operators. This would results in huge costs in the IT area, mainly due to software replacement.

Consideration of the above threats caused by implementation of the $4^{\text {th }}$ Railway Package suggests that small local companies may disappear from the rail market, since not every company is ready for large costs to be born on the railway stock.

\section{Admission and certification rules according to the "new" directive}

The most important objective of the $4^{\text {th }}$ Railway Package related to the field of certification and approval of vehicles in the European Community is the unification of the rules for issuing the certificates and rules for putting the vehicles into service.

In the field of certification, the main change will consist in implementation of the certificate template for all the Member States - the Single Safety Certificate (SSC). According to the scope of certification, the document will be issued by ERA and/or NSA (National Security Office - in Poland the Office of Rail Transport UTK fulfills the function). In the case of the applications covering the area of one country, the certification body will be NSA or ERA + NSA, while for applications covering the area of at least two countries only ERA + NSA may issue the certificate. The purpose of a new certification procedure is a single evaluation of the applicant, regardless of the area of its operation, as well as better harmonization of the rules and evaluation requirements. Moreover, the changes shall strengthen the relationship between the application assessment and supervision, and reinforce the emphasis placed on a risk-based approach as well as better cooperation between the NSA in the supervision process [2]. gólności lokalnych przedsiębiorstw, np. kolei regionalnych

- niekonkurencyjność polskich przewoźników na tle innych w wyniku gorszego stanu taboru, mniejszego budżetu na modernizację w porównaniu $\mathrm{z}$ innymi

- możliwość stosowania cen dumpingowych (dumping: sprzedaż towarów i ustug poniżej kosztów ich wytworzenia lub świadczenia albo ich odsprzedaż poniżej kosztu zakupu w celu eliminowania innych przedsiębiorców) przez dużych przewoźników zagranicznych na terenie Polski, przez to możliwość wyeliminowania z rynku lokalnych przedsiębiorców lub likwidacja istniejącego obecnie rozróżnienia przejazdów międzynarodowych oraz krajowych powodujących konieczność szybkiej modernizacji poszczególnych linii bądź ich likwidacja.

Z kolei najbardziej kosztownym zagrożeniem w tej grupie może być ustanowienie wspólnych systemów informacyjnych i zintegrowanych systemów biletowych dla wszystkich operatorów kolejowych, co skutkuje poniesieniem ogromnych kosztów w obszarze informatycznym głównie ze względu na zmianę oprogramowania;

Biorąc pod uwagę ww. zagrożenia wynikające $\mathrm{z}$ wdrożenia IV pakietu kolejowego można stwierdzić, że niewielkie lokalne przedsiębiorstwa mogą zniknąć w rynku kolejowego, a nie każde przedsiębiorstwo jest gotowe na kosztowne inwestycje w szeroko pojęty tabor.

\section{Zasady dopuszczenia i certyfikacji według „nowej” dyrektywy}

Najważniejszym założeniem IV pakietu kolejowego w obszarze certyfikacji i homo-logacji pojazdów we wspólnocie jest ujednolicenie zasad wydawania certyfikatów oraz zasad dopuszczania do eksploatacji pojazdów.

W obszarze certyfikacji główną zmianą będzie wdrożenie szablonu certyfikatu dla wszystkich państw członkowskich - Jednolity Certyfikat Bezpieczeństwa (Single Safety Certificate (SSC)). W zależności od zakresu certyfikacji dokument będzie wydawany przez ERA i/lub NSA (Krajowy Urząd Bezpieczeństwa - w Polsce funkcję tę pełni UTK). Dla wniosków obejmujących obszar jednego państwa organem certyfikacyjnym będzie: NSA lub ERA + NSA, natomiast dla wniosków obejmujących obszar co najmniej dwóch państw będzie tylko ERA + NSA. Celem wprowadzenia nowej procedury certyfikacji jest jedna ocena wnioskodawcy bez względu na obszar jego działania, ale także większa harmonizacja zasad i wymagań oceny. Dodatkowo zmiany spowoduja wzmocnienie relacji pomiędzy oceną wniosku, a nadzorem i nacisku na podejście oparte na analizie ryzyka oraz możliwość współpracy między NSA w procesie nadzoru. 
As regards the authorization of placing the vehicle into service (approval) - Authorization of Placing on the Market (APOM) / Vehicle Authorization (VA), the changes result mainly in formulation of a single application assessment, regardless of the vehicle operation area and in increased harmonization of the requirements and evaluation principles. The division of the certification body (in this case the authorizing entity) is similar to the case of the certification field, i.e. the applications covering the area of a single state are examined by NSA or ERA + NSA, while the applications covering the area of at least two countries by ERA + NSA. The NSA's duty will be, among others, to supervise the vehicle operation and maintenance, and to carry out the carrier's tasks (SMS - safe marshalling the vehicle into a train and verification of compatibility with the route) [2].

\section{Summary}

The European rail market has for many years strived to unify the law, the rules of putting the vehicles into service, as well as certification and approval of the vehicles. For this purpose, four railway packages have been successively created and, afterwards, modified and updated in the next years in response to the problems arisen on the common railway market. Each package consists of normative documents, mainly directives and regulations. The fourth, the latest railway package consists of six aforementioned documents, i.e. Regulation No. 2016/796, Directive 2016/797, Directive 2016/798, Regulation No. 2016/2338, Directive 2016/2370 and Regulation No. 2016/2337.

Implementation of the $4^{\text {th }}$ Railway Package may result in the threats that can be divided into two groups, depending on the cause of the threat. The first group includes the threats resulting from implementation of the package technical documentation, while the second one covers the risks related to management and market opening projects.

What concerns the vehicle homologation and certification, the most significant change will consist in implementation of a unified security certificate template for all the community members.

The $4^{\text {th }}$ Railway Package gives rise to some risks, but a positive aspect of the package implementation is also noticeable. The main objectives of the package are to reduce the costs incurred by the railway companies existing on the market, to facilitate market entry for new players, to remove the obstacles impeding creation of a uniform European rail market, to support competitiveness and innovation in domestic passenger markets, and a higher level of security, interoperability and reliability of the European rail network.
W obszarze dopuszczenia pojazdu do eksploatacji (homologacji) - Authorization of Placing on the Market (APoM) / Vehicle Authorization (VA) zmiany prowadzą głównie do jednej oceny wniosku niezależnie od obszaru eksploatacji pojazdu oraz do zwiększenia harmonizacji wymagań i zasad oceny. Podział organu, w tym przypadku autoryzującego, jest analogiczny do obszaru certyfikacji, tzn. dla wniosków obejmujących obszar jednego państwa: NSA lub ERA + NSA, natomiast dla wniosków obejmujących obszar co najmniej dwóch państw: ERA + NSA. Obowiązkiem NSA będzie m.in.: nadzór nad eksploatacją pojazdu i utrzymaniem oraz realizacja zadań przewoźnika (SMS - bezpieczne włączenie pojazdu w skład pociagu i weryfikacja kompatybilności z trasą).

\section{Podsumowanie}

Europejski rynek kolejowy od wielu lat dąży do ujednolicenia prawa, zasad dopuszczania pojazdów do eksploatacji, a także certyfikacji i homologacji pojazdów. W tym celu powstały kolejno cztery pakiety kolejowe, które w kolejnych latach zostały zmodyfikowane i zaktualizowane zgodnie $\mathrm{z}$ powstałymi problemami na wspólnym rynku kolejowym. Każdy z pakietów składa się z dokumentów normatywnych, głównie dyrektyw oraz rozporządzeń. Czwarty, najnowszy pakiet kolejowy składa się z sześciu ww. dokumentów, tj.: Rozporządzenia nr 2016/796, Dyrektywy 2016/797, Dyrektywy 2016/798, Rozporządzenia nr 2016/2338, Dyrektywy 2016/2370 oraz Rozporządzenia nr 2016/2337.

Wdrożenie czwartego pakietu kolejowego może skutkować powstaniem zagrożeń, które można podzielić na dwie grupy w zależności od przyczyny zagrożenia. Pierwsza grupa to zagrożenia wynikające $\mathrm{z}$ wdrożenia dokumentacji technicznej pakietu, a druga to zagrożenia związane z projektami zarządzania i otwarcia ryn$\mathrm{ku}$.

W obszarze homologacji i certyfikacji pojazdów, największą zmianą będzie wdrożenie ujednoliconego szablonu certyfikatu bezpieczeństwa dla wszystkich członków wspólnoty.

Czwarty pakiet kolejowy niesie za sobą pewne zagrożenia, ale jest także pozytywny aspekt wdrożenia pakietu. Głównymi celami pakietu są zmniejszenie kosztów ponoszonych przez istniejące na rynku przedsiębiorstwa kolejowe, ułatwienie wejścia na rynek nowym podmiotom, usunięcie barier $\mathrm{w}$ tworzeniu jednolitego europejskiego rynku kolejowego, wspieranie konkurencyjności i innowacji na krajowych rynkach pasażerskich, a ponadto wyższy poziom bezpieczeństwa, interoperacyjności oraz niezawodności w europejskiej sieci kolejowej. 


\section{Bibliography / Bibliografia}

[1] Ustawa z dnia 28 marca 2003 r. o transporcie kolejowym (Dz. U. 2003 Nr 86 poz. 789)

[2] Czwarty Pakiet Kolejowy - likwidacja barier dla konkurencyjnego transportu kolejo-wego. Plany wdrożenia czwartego pakietu kolejowego przez Agencje Kolejowa Unii Europejskiej A. Harassek, P. Cukierski, Warsztaty SIRTS, Warszawa 2017 r.

[3] Bariery liberalizacji europejskiego rynku kolejowego i perspektywy zmian A. Mężyk, Uniwersytet Technologiczno-Humanistyczny w Radomiu, 2012 r.

[4] Ewolucja celów polityki transportu kolejowego w Europie M. Garlikowska, Centrum NaukowoTechniczne Kolejnictwa, Zeszyt 149

[5] Dyrektywa 2001/12/WE Parlamentu Europejskiego i Rady z 26 lutego 2001 roku zmieniajaca Dyrektywe Rady 91/440/EWG w sprawie rozwoju kolei Wspólnoty

[6] Dyrektywa 2001/13/WE Parlamentu Europejskiego i Rady z 26 lutego 2001 roku zmieniajaca Dyrektywe Rady 95/18/WE w sprawie koncesjonowania przedsiębiorstw kolejowych

[7] Dyrektywa 2001/14/WE Parlamentu Europejskiego i Rady z 26 lutego 2001 r. w sprawie alokacji zdolności przepustowej infrastruktury kolejowej i pobierania opłat za użytkowanie infrastruktury kolejowej oraz przyznawanie świadectw bezpieczeństwa

[8] Dyrektywa 2001/16/WE Parlamentu Europejskiego i Rady z 19 marca 2001 r. w sprawie interoperacyjności transeuropejskiego systemu kolei konwencjonalnych

[9] Dyrektywa 2004/49/WE Parlamentu Europejskiego i Rady z dnia 29 kwietnia 2004 r. w sprawie bezpieczeństwa kolei wspólnotowych oraz zmieniajaca dyrektywę Rady 95/18/WE w sprawie przyznawania licencji przedsiębiorstwom kolejowym, oraz dyrektywe 2001/14/WE w sprawie alokacji zdolności przepustowej infrastruktury kolejowej i pobierania optat za uzytkowanie infrastruktury kolejowej oraz certyfikację w zakresie bezpieczeństwa (Dyrektywa w sprawie bezpieczeństwa kolei)

[10] Dyrektywa 2004/50/WE Parlamentu Europejskiego i Rady z dnia 29 kwietnia 2004 r. zmieniajaca dyrektywe Rady 96/48/WE w sprawie interoperacyjności transeuro-pejskiego systemu klei dużych prędkości $i$ dyrektywę 2001/16/WE Parlamentu Europejskiego i Rady w sprawie interoperacyjności transeuropejskiego systemu kolei konwencjonalnej

[11] Dyrektywa 2004/51/WE Parlamentu Europejskiego i Rady z dnia 29 kwietnia 2004 r. zmieniajaca dyrektywę Rady 91/440/EWG w sprawie rozwoju kolei wspólnotowych

[12] Rozporzadzenie (WE) nr 881/2004 Parlamentu Europejskiego i Rady z dnia 29 kwietnia 2004 r. ustanawiajqce Europejskq Agencję Kolejowq (Rozporzqdzenie w sprawie Agencji)

[13] Dyrektywa 2007/58/WE Parlamentu Europejskiego i Rady z dnia 23 października 2007 r. zmieniajaca dyrektywę Rady 91/440/EWG w sprawie rozwoju kolei wspólnotowych oraz dyrektywę 2001/14/WE w sprawie alokacji zdolności przepustowej infrastruktury kolejowej i pobierania opłat za użytkowanie infrastruktury kolejowej

[14] Dyrektywa 2007/59/WE Parlamentu Europejskiego i Rady z dnia 23 października 2007 r. w sprawie przyznawania uprawnień maszynistom prowadzacym lokomotywy i pociagi $w$ obrębie systemu kolejowego Wspólnoty

[15] Rozporzqdzenie (WE) nr 1370/2007 Parlamentu Europejskiego i Rady z dnia 23 października 2007 r. dotyczqce ustug publicznych $w$ zakresie kolejowego i drogowego transportu pasażerskiego oraz uchylajqce rozporzadzenia Rady (EWG) nr 1191/69 i (EWG) nr 1107/70. 